cant it looks in the company of Giant Petrels and Wandering Albatrosses! These birds, all typical of Southern coasts and keen ship-followers, associate freely in pursuit of the ferry boats crossing the Cook strait between Wellington and Picton. Whenever refuse is tipped out, the gulls arrive first. Then the Giant Petrels with their hooded, murderous eyes crash land heavily among the scraps and the gulls fly up like so many sparrows. Ultimately the Albatross is able to manoeuvre itself into the vicinity of the food, of which it takes possession, thrusting viciously at any petrel which might come too close. It seems the arbiter of the Southern ocean expanses, following ships tirelessly with massive hunched shoulders holding the bowed wings rigidly in position: more than any other bird it symbolises the majesty and splendour of the ocean spaces.

Right at the other end of the scale we have one of New Zealand's most interesting birds, the Wry-billed Plover. It is so called because its bill points somewhat to the right. I believe it is the only living bird able to claim this distinction.

Canada is such a large country that it has a varieity of habitats with birds characteristic of each. For me, the song of the Golden-crowned Sparrow will always have a special appeal. At that joyous time in the Northern Hemisphere when the trees seem to become greener every day, the song of the Gclden-crowned Spar. row is at once pure, austere, and sad. The three deliberate notes in cadence, rather low in pitch, strike the ear and heart poignantly with their melancholy.

What a contrast is presented by the ebullient, extroverted notes of the Western Meadowlark! Their blithe, bubbling loudness pours joyfully through the car window as one drives through open country. Another contrast is the fruity squawking of the Yellow-headed Blackbird, eloquent of the marsh-fringed lakes and sloughs.

Lastly I must choose a bird from the Prairies. Around one stretches mile after mile of prairie, not exactly flat, but rising and dipping only just perceptibly-thus enhancing the sensation of vastness. Above is the grey sky. Suddenly, a trickle of notes is poured out, notes unlike those of any other bird save the Veery. No bird is seen, the song. seems to be "utitered by nothingness out of nothingness"-by some disembodied spirit. It is the song of the Sprague's Pipit. To my mind, no bird is more evocative of the wide prairie.

Passing now from birds to human beings, I would like to take this oppontunity of thanking the many Canadian birders who so willingly gave of their time, transport, and bird wisdom in order that my expeditions should be successful.

\title{
1960 - The Year of the Owls
}

by Stuart Houston, Saskatoon

The year 1960 máy be noted for many things, but for me and many others in the Yorkton area it will always be remembered as "the year of the owls". It got off to a good start on January 2, when I drove up to High Hill to band a Barred Owl caught by Steve and Anton Waycheshen. The Barred Owl is a new species on the Saskatchewan list (see Blue Jay 17:94, 1959 and 18:5, $1960)$ and this was the first individual to be banded in Saskatchewan.

Then came the onslaught of Boreal (Richardson's) Owls. Gary Anweiler snared the first one on
January 7 (see Blue Jay 18:61-63, 1960). By January 22, we had banded four and Gary was keeping a fifth for study purposes. We arranged to show Gary's bird on CKOS-TV, Yorkton, on Monday evening, January 25, and meanwhile Martin Busch of Calder caught another. During the special 15-minute program devoted exclusively to a discussion of Richardson's Owls, Gary and I each had an owl perched on our wrist, secured by falconer's jesses. The owls snapped and flapped their wings at the audience and from that moment "Richardson's radiology for three years. His new address is 2401 Hanover Ave, Saskatoon. 


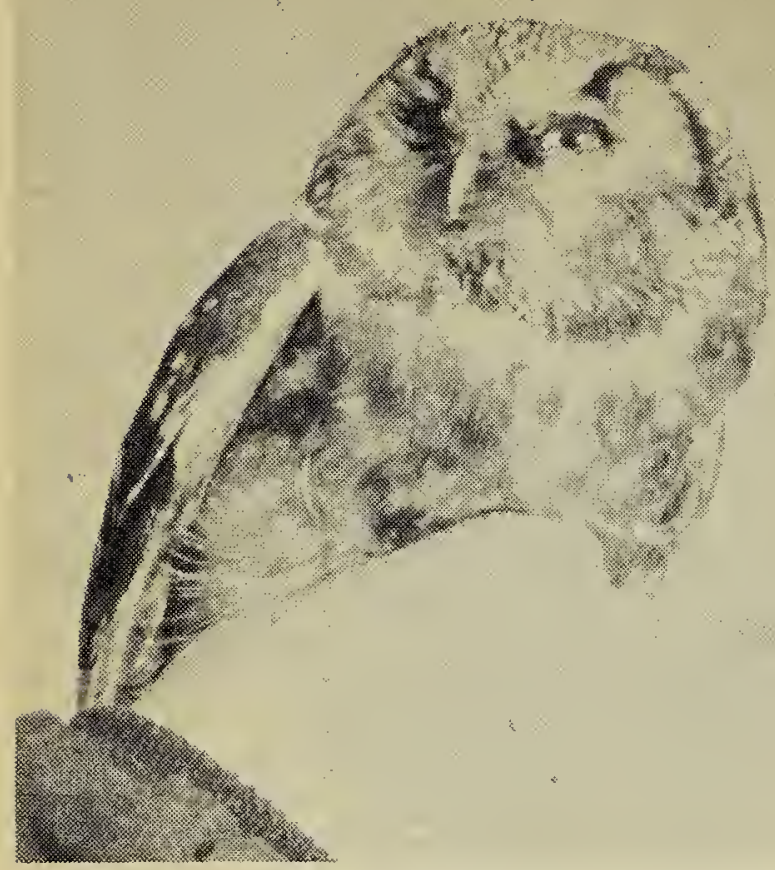

Photos by Stuart Houston Boreal (Richardson's) Owl

Owl" was a household name throughout the CKOS viewing area. Even those who missed the program heard all about it from their neighbors. Before the program was over, Steve Shebeluk of Calder left his set and dashed out to his machine shed to catch the little owl that he had seen while doing evening chores. That Saturday, Gary and I travelled over 300 miles to pick up Richardson's Owls from Fenwlood and Arran and from Inglis in Manitoba, with an added bonus of a Saw-whet Owl at Hazelcliffe.

The interest aroused by the T.V. program of. January 22 was largely responsible for the opportunity that followed-a weekly T.V. program during the spring migration season. Again a Richardson's Owl was on the scene to get the first program off to a good start on March 15-though I had to drive 120 miles over drifting roads in a blinding snowstorm after midnight to get the bird from Philip Adams, who had trudged two miles on foot through deep snow to meet me. This little owl captivated the audience the nexit evening and well repaid the effort involved in getting him. He was banded and released immediately after the program.

The twenty-fifth individual of this species was banded April 27. We were sure this was a "world record" and Chan Robbins kindly checked through the U.S. Fish \& Wildlife Service banding records to confirm this. Never before had more than three Boreal Owls been banded in any one year by the two thousand or more banders on this continent; the all-time total banded to the end of 1957 was only twenty.

Gary Anweiler and Bill Horseman were not content with our 1959 Great Horned Owl banding total of 70 , and they talked all winter of banding 100 this year. Such enthusiasm is not to be discouraged, so to help locate sufficient nests I offered a prize of one Peterson's Field Guide to the Birds for the boy in the CKOS-TV area finding the most owl nests. The results far exceeded my expectations and on the final program on May 17 it was my pleasure to present three field guides-one to 16-year-old George Chopping of Dubuc, who found 16 owl nests (and I should add that he found another four later in the month); one to 11-year-old Myles Ferrie, of Invermay, who also found 16 nests; one to Ronald Hilderman of MacNutt, who found 10 nests. Each boy had a companion who had tramped with him-Doug Lambie of Dubuc, Eddie Shepherd of Invermay, and Timmie Wendell of MacNuttand these boys were each presented with a year's subscription to the Blue Jay. Although the Horned Owl nesting density averaged one pair for each one or tivo square miles in each of the areas, it took many miles of walking to check every bush on a section of land in parkland country. For example, Chopping walked 31 miles in one day to find four Horned Owl nests and another day be walked 25 miles to find three owl nests. My

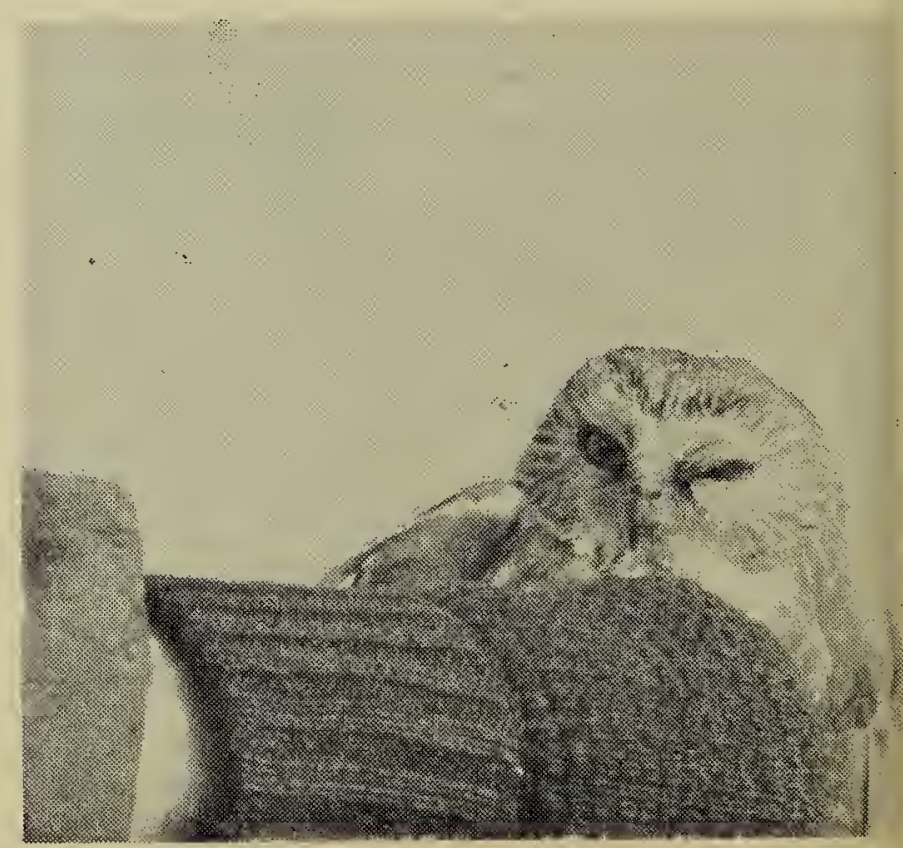

Saw-whet Owl caught by Jack Provick at Hazelcliffe 


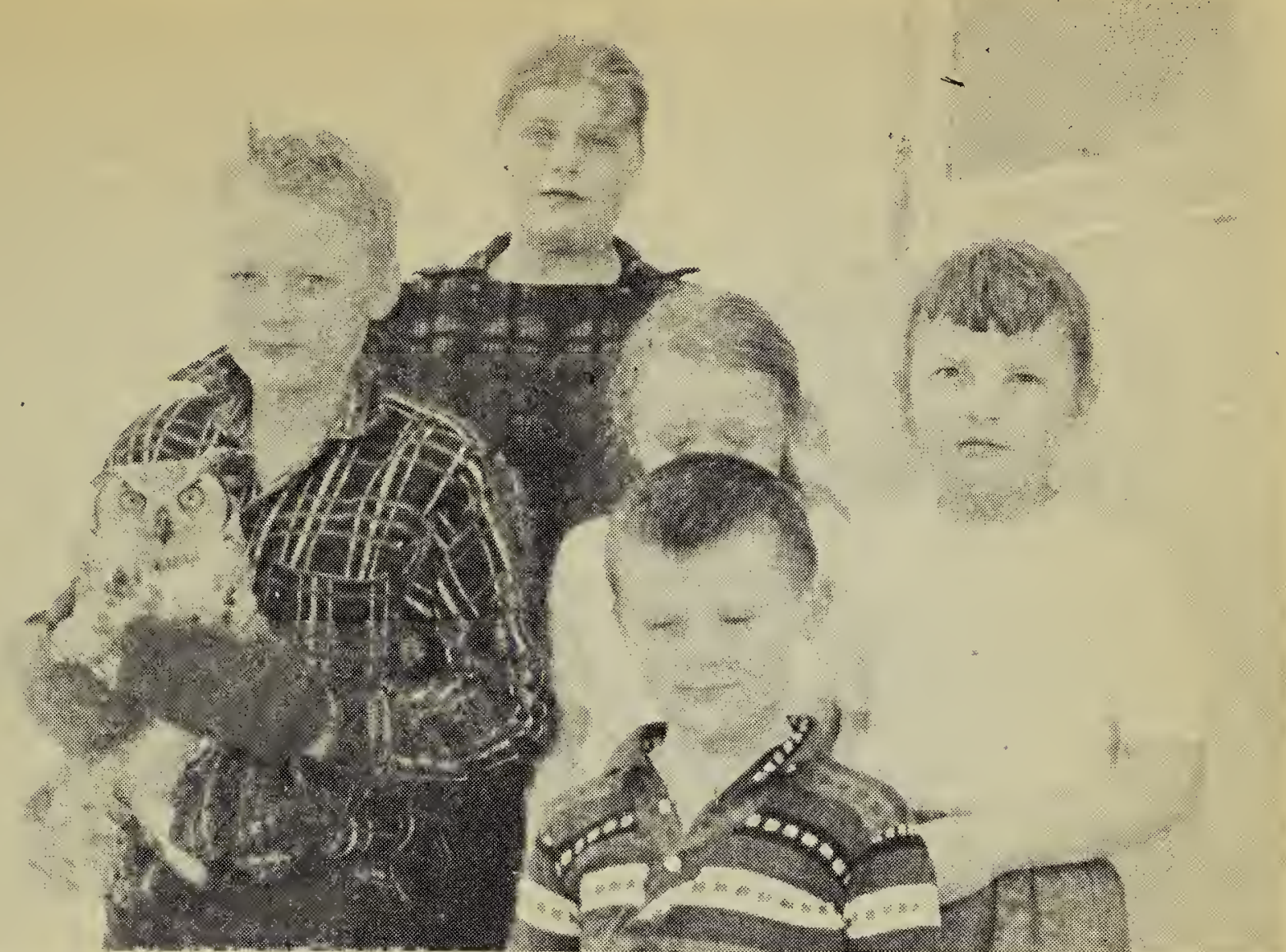

The finst Horned Owl bandery by Dr. Houlditon in 1960. For the story of how this adult owl was caught by these quick-thinking students of Armstrcing School see Blue Jay XVIII:89, Sharon Pearce (Boys' and Girls' Section)

wife ungraciously remarked that the boys would have been further ahead if they had bought a field guide and saved their shoe leather!

The first nest of the year had been found alongside the C.N.R. track near Rhein by engineer Phil Walt of Melville, who had seen the adult bird sitting closely on the nest since February 28! When we visited the nest on our first banding trip on May 8, the four young were well advanced-but we had to prod the adult off with a long pole before Anweiler could go up and band the young. An occasional drop of rain was just starting to fall, and the old bird was sheltering the young with outstretched wings.

Sunday, May 15, was designated as "owl banding day" and Anweiller, Horseman and I set out soon after dawn. In the high wind, Anweiller netted a Short-eared Owl sitting on seven eggs south of Dubuc-the first of this species I had ever banded, bringing my total to 142 species. Chopping and Lambie showed us 13 Horned Owl nests with young of banding age, and two nests with young too small to band. That afternoon we stopped at two nests at Langenburg and went on to MacNutt where we visited another six nests before dark. The total for the day was 52 young Horned Owls banded in 21 nests. The boys, their tongues hanging out after a strenuous day of tree climbing, announced proudly that this record should stand for some time.

On Sunday, May 22, Anweiler and I banded another 28 Horned Owls in 13 nests located near Saltcoats by Bill Horseman. On the May 23 holiday, we banded 24 Horned Owls in 11 nests near Invermay. Other birds were banded in the evenings until the season's total was no less than 150 Horned Owls banded in 66 nests.

It is unusual for a Horned Owl to raise four young to maturity and this seems possible only in years of abundant food supply. Two nests at Dubuc and one at Invermay, in addition to the one near Rhein, raised four young this year. Twenty nests had three young each and 32 had two young (though three of these had a third young too small to band). Five nests were known to have raised only one young, but in five other cases where only one young was banded, older nest-mates had already left the nest.

The first 44 nests visited ito May 22 raised 108 birds or a remarkable average of 2.48 young per nest. Data 
on the last 22 nests do not permit calculations as young had already left some of these nests. In addition ito the 66 successful nests, two nests had blown down in storms and five had been deserted before the young matured. One owl was still sitting on a single infertile egg south of Invermay on May 23. We knew of five additional nests that time did not permit us to visit.

Mid-May is certainly the optimum time for banding Horned Owls in the Yorkton area. On May 15, only four nesits contained young too small to band-and two of these nests were revisited later. However, of fifteen nests visited on May 23, only eight still contained young. Young were located nearby at three nests and at four the young could not be located at all. The hatch was remarkably uniform and the latest nest seemed to be one south of Salitcoats which contained two newly hatched young and one egg on May 22.

A record was kept of all food found in the nests. Of 25 Horned Owl nests visited up to and including May 15, only two nests had no food on hand. We found 3 Coots, 2 Crows, 1 Blue-winged Teal, 1 Horned Grebe, 1 Mallard, 1 long-eared Owl and 1 Deer Mouse. Seven nests contained a total of eight rabbits. But by far the biggest food item was the Pocket Gopher, as 16 of these nests contained an amazing total of 48 Pocket Gophers. One nest near Dubuc had two young rabbits and 15 Pocket Gophers piled three deep so that there was hardy room for the two young owls!

Of 32 later nests, nine contained no food. The remainder yielded 8 Coots, 3 Mallards, 1 Pintail, 1 Shoveler, 1 Blue-winged Teal, 1 Yellowheaded Blackbird, 4 rats, 2 rabbits and 3 mice. Nine nests each contained a single Pocket Gopher. At this stage, the young owls were well feathered and no doubt had larger appetites, thus leaving less untouched in the larder for us to see.

It is noteworthy that this year we again failed to find a single upland game bird in an owl nest (see Blue Jay 17:106-7, 1959). Once more we failed to find the slightest evidence that poultry had been molested by the owls. It musit be extremely rare, therefore, for an owl to kill dom- estic poultry or upland game during the nesting season in the "parkland area' of Saskatchewan. It is true that each fall one hears. of some farmer who loses poultry to owls. The damage is believed to be done by an occasional young owl who is perhaps a poor hunter and develops a taste for domestic poultry. This was true of one of the young owls banded north of Saltcoats in 1959. It was killed on the evening of October 3 , only half a mile from the nest where it was banded, while killing the seventh domestic chicken in seven nights! These individuals of course should be shot, but one must remember that they are the exception rather than the rule. I know of many farmers in this area of high owl density who have had owls nesting nearby for many years and never lost a chicken.

I read with interest Dick Lumsden's "Plea to Banders for Caution in Handling Great Horned Owls" (Blue Jay 18:18-19, 1960). I have been acutely aware of this danger, for when I was a youngsiter, two different boys in the Yorkton area lost an. eye while visiting the nest of a Great Horned Owl. For this reason, I have always warned people never to climb a Horned Orvl nest alone. We too have found that it is mosit dangerous to climb an owl's nest at dusk. However, we have never worn safety masiks, as they can be awkward in climbing a tree. Certainly in the comparatively low nesits in our prairie parklands (rarely more than 30 feet above the ground), we have relied on SAFETY IN NUMBERS. The parent owl will often attack a lone boy climbing to her nest, but will be bewildered by the sight of four to six noisy boys, each brandishing a stick, fanned out around the botitom of the tree. Three times. this year we had to throw sticks at the owl coming in to attack, and thus deflected her. At other nests the waving, yelling boys successfully dissuaded the owls from any thought of attacking the lad at the nest. Our reserve protection we have only used once-at one high nest in an open clearing in 1959, I fired a shotgun blast in the air to frighten the owl which had struck Anweiler with its wing late the previous evening. Although the owls 
must be watched with great caution, it is our experience that an even greater danger is that of falling from the tree. This year one lad fell 25 feet and landed on his head-a bit shaken, but miraculously unharmed. I should add that the sharpest blow to connect with my head this year was an unexpected one administered by a Long-eared Owl!

The next owl to take the limelight was the Short-eared Owl. Clarence Fick found a nest with seven eggs northeast of Yorkton on May 4, and Mervin Mroske found a nest with one egg on IMay 8. Alec Jowsey of Barvas and Jim Trowell of Saltcoats each found nests with six eggs on May 13. These first nests were in unthreshed swaths on the stubble and represented the first nesting dates I had for the Short-eared Owl in the Yorkton area. Through May and June, more reports poured in. Some of the later nests were in the more usual habitat of long grass and on the average seemed to fare better, since many of the early nests were dstroyed during spring harvest operations and when the stubble was plowed or burned. Some farmers took great care to leave a piece of land unworked around the nesit and some of these nests, in spite of their resulting exposed position, we know to have been successful. In every case, the farmer told me that he had never found a nest of this owl in pasi years. The population of this owl in the Yorkton district in 1960 was at least ten times higher than its usual low level; in fact, I would estimate that it had increased one hundredfold. It also seems quite definite that this sudden increase resulted from the abnormally high mouse population consequent to nearly half of the 1959 crop lying unharvested under the snow over winter.

Ed Ball, seven miles south of Willowbrook, found three nests on one 320 -acre field of stubble. One nest was deserted at once, but the young disappeared at the rate of one daily from the other two nests. No tracks of animals could be found and it is supposed that a Horned Owl may have taken one each night or that this might represent another case of "cannibalism" by the Shorteared Owls themselves.

Perhaps the observations of Joe Gillis at a nest one mile south of Theodore can help us understand the actions of this species in time of adversity. This nest contained six thriving young, well supplied with food up to and including June 3 . That day one of the adults was found beneath the power line with a broken wing. When I visited the nests on June 4, the three older young were still thriving, but the dismembered and partially eaten remains of the younger three were scattered around the nest. Presumably the remaining parent could not hope to feed all six and so the three smallest were sacrificed in the interests of the preservation of the species.

At the time of writing, our Shorteared Owl banding total for the year stands at 68 ycung birds in 21 nests. I have Stanley Zazelenchuk of Stornoway to thank for banding four of these nests, and Jack Provick of Hazelcliffe for three. Of the other nests baanded, Albert Walter of Dunleath, Keith Sherwin of Tonkin, and George Chopping of Dubuc, each located two, and Joe Gillis of Theodore, Ken Schwartz of Stornoway, Bill Bobyk and Alec Jowsey of Dunleath, and Don Rogers, Jack Zepp and Clarence Fick of Yorkton, each located one. In addition I made a number of futile visits to nests that had been deserted or destroyed.

It seems that the high levels of the mouse population this year were equally attractive to the Long-eared Owl, for some unusually high nesting densities were found this year. Sammy Bruce found two nests within 100 yards of each other, and a third rest on the same half-section, northeast of Saltcoats. One mile away, Herbie Cross also found three nests on his father's farm. South of Willowbrook, Clifford and Llewellyn Lovelace found seven Long-eared

Actoss the province at Bladworth, P. Lawrence Beckie makes a similar estimate of the increase in Short-eared Owls in 1960. He writes: "Over the last year I have noticed that the numbers of the Short-eared Owl have increased $100 \%$ in our district. Last year I did not see a single bird, but this year I believe there are three pairs nesting along the road within three miles of home." Lawrence Beckie also mentions finding his first Long-eared Owl's nest since 1947 on May" 31 of this year.-Ed. 
Owl nests on two sections of land. Bruce Kreba of Dunleath also found two nests not more than 150 vards apart. Sitanley Zazelenchuk of Siornoway located five nests within a two-mile radius, and the 22 yrung were all banded Time did not permit return visits to many of the nests that were located, but the total of 73 young banded from 18 nesits was still most satisfaclory.

I had never dreamed it would be possible to band over 300 owls in just over six months. It was only possible through the cooperation of many people and the energetic assistance provided by the boys whose names I have mentioned.

\section{Mass Mortality of Western Grebes}

by R. W. Nero, Saskatchewan Museum of Natural History

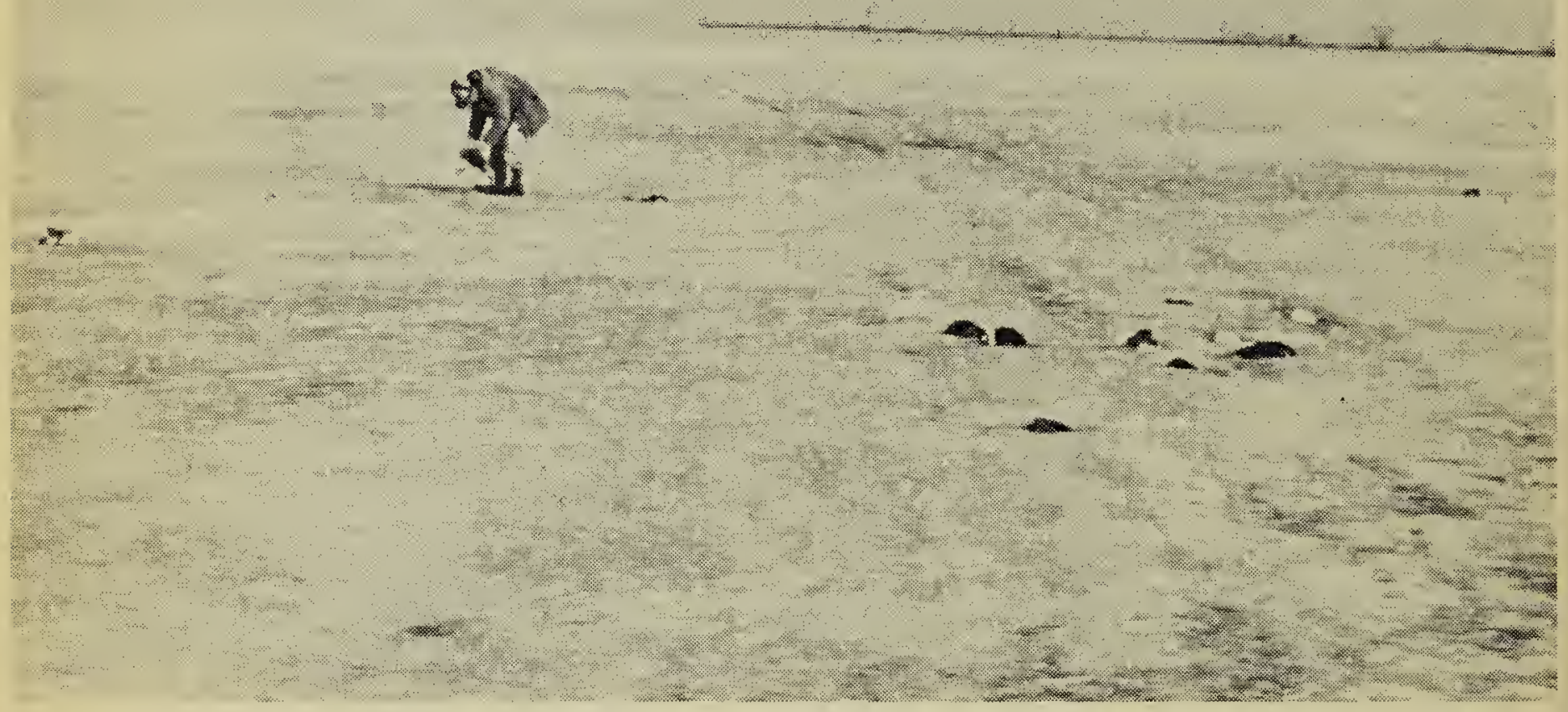

Photo by $F . W$. Lahrman

R. W. Nero examining Western Grebes frozen in the ice at Lake Newell, Brooks, Alberta.

On March 17, 1960, Fred Sharp (Provincial Naturalist, Ducks Unlimited), informed me of a mass mortality of the Western Grebe (Aechmophorus occidentalis) at a lake in southeastern Alberta. Probably more than 1000 grebes perished as the result of a sudden freeze-up during the period of November 13 to 16 , 1959, on Lake Newell, south of Brooks, Alberta. A report prepared by Sharp gives some details of his observations:

"On November 13th, on returning from a trip to southern Alberta J spent some three hours on the shores of Lake Newell observing the migration of waterfowl from the lake. The day was extremely cold: $-19^{\circ}$ with a 12 m.p.h. S.E. wind blowing. There was a snow cover of 3.5 inches, and the day was clear. However, with the weather conditions what they were the wind chill would be in the $-35^{\circ}$ zone. The bays on the lake were frozen over at this time as it had been quite cold since the start of the month. On November 5 th, for example, the temperature had dropped to $-7^{\circ}$ with a 13 m.p.h. wind. On the $13 \mathrm{th}$, vapor was rising from the open body of water in the lake, collecting into a cloud mass and falling as snow over the village of Tilley nine miles east of the lake. At this time approximately twothirds of the lake was still open, but what with the extreme cold and the wind, it was freezing in very fast; each incoming wave would wash up on the existing ice line and form a 